\title{
AKAR HISTORIS DAN DOKTRIN ALIRAN ADARI (TINJAUAN SELINTAS)
}

\author{
Indra Harahap \\ Universitas Islam Negeri (UINSU) Medan \\ indraharahap@uinsu.ac.id
}

\begin{abstract}
Abstrak
Kemunculan dan perkembangan ADARI tidak bisa dipisahkan dari keberadaan agamaagama resmi di Indonesia. Sebab pada dasarnya para pendiri secara personal adalah orangorang yang merupakan bagian dari para penghayat agama resmi. Menariknya, hal ini tampak dalam perkembangan ajaran ADARI yang disebut sebagai upaya akumulatif dari berbagai praktek keberagamaan. Hal ini sangat jelas tampak dalam ajaran mengenai ketuhanan yang tidak bisa dibedakan dengan prevalensi agama resmi. Berdasarkan beberapa referensi, dinyatakan bahwa munculnya ajaran ADARI dipelopori oleh Mangun Widjoyo saat berada di penjara di Wirogunan, Yogyakarta. Bahkan, menurut pengakuannya, selama di penjara dia mengadakan perenungan atau meditasi, sehingga instruksi dalam bentuk wangsit datang kepadanya untuk segera mengembangkan pengajaran tentang hasil perenungannya, yaitu Manunggaling Kawula Gusti, dan dia diangkat sebagai nabi yang juga sebagai inkarnasi tuhan.
\end{abstract}

Kata kunci:Aliran ADARI, Doktrin Ketuhanan, Manunggaling Kawula Gusti

\section{Abstract}

ADARI's flow of birth and development cannot be separated from formal religion. Because indeed the founding fathers personally are people who are part of the practice of formal religion. Interestingly, it turns out that in the development of $A D A R I$ 's doctrine, this can be called an accumulation effort from various religions. This is very clearly seen in his doctrine of divinity which is not distinguished as the prevalence of formal religions.Based on several references, it was stated that the emergence of ADARI's teachings was pioneered by Mangun Widjoyo while in prison (in a cell) in Wirogunan, Yogyakarta. In fact, according to bis confession, during his time in prison he held contemplation or meditation, so that the instructions in the form of wangsit came to bim to immediately develop a teaching on the results of his contemplation, namely Manunggaling Kawula Gusti, he was appointed as a prophet who was also God's incarnation.

Keywords: ADARI's Sect, Doctrine of God, Manunggaling Kawula Gusti

\section{Pendahuluan}

Dalam kajian historis agama-agama, terutama agama-agama semitik (semitic religions) seperti Hindu, Budha, Kristen, Katholik, dan Islam secara nyata harus diakui secara jujur bahwa agamaagama ini telah berhasilkan melahirkan suatu tatanan moral religious dan suatu peradaban yang berpengaruh luas di masyarakat. Karena memang semua agama-agama yang disebutkan ini memiliki 
doktrin semangat yang kuat sebagai pendorong bagi kemajuan peradaban dunia. Doktrin-doktrin agama-agama ini terformulasi secara sempurna dalam bentuk pengabdian dan pengorbanan yang merupakan sepenuhnya bersumber dari sesuatu yang di laur manusia, yaitu Tuhan.

Dalam perkembangan berikutnya dalam konteks perkembangan historis agama-agama kemapanan agama-agama formal ini secara pelan dan pasti telah mengalami pergerseran yang disebabkan kenyataan kehidupan yang telah berubah. Perubahan kehidupan ini-terutama sosialtentu saja memberi pengaruh yang berarti bagi munculnya kecenderungan cara beragama yang baru yang dapat disebut mengancam kemapanan agama-agama formal tersebut. Dalam kaitan ini misalnya di Indonesia telah muncul berbagai aliran-aliran kebatinan yang diyakini sebagai suatu cara memaknai ajaran agama yang dapat lebih mengarahkan manusia itu ke dalam suatu tingkat kepercayaan yang dianggap sejajar atau paling tidak memiliki kedekatan khusus dengan agama.

Makalah ini secara singkat akan memaparkan sekilas tentang akar dan perkembangan aliranaliran kebatinan, yang secara khusus lagi dibatasi pada aliran kebatinan ADARI yang belum banyak diamati para ahli dan peneliti aliran kebatinan di Indonesia. Pembatasan ini dimaksudkan supaya kajian lebih teroganisir dan terarah disebabkan memang kajian tentang ADARI sejauh ini memanglah dapat disebut tertinggal untuk tidak kaji sama sekali. Oleh sebab itu, makalah ini dapat secara reprentasi menjelaskan tentang akar historis dan perkembangannya.

\section{Sekilas Mengenal Aliran ADARI}

Melihat akar historis aliran kebatinan ADARI ini tentu saja tidak dapat dipisahkan dari historis Bangsa Indonesia merupakan bangsa yang terdiri dari berbagai suku bangsa, adat istiadat, bahasa dan agama (majemuk). Karena memang dari kemajemukan bangsa Indonesia merupakan sumber potensi kekayaan budaya bangsa yang sangat besar dan berharga, tetapi di sisi lain kemajemukan bangsa Indonesia yang dapat menjadi sumber potensi bagi terlahirnya ketegangan, konflik, perbedaan kesalah pahaman dan memang yang seharusnya disalahkan, terlebih lagi potensi untuk melahirkan aliran kebatinan. ${ }^{1}$

Dari penulusuran akar historisnya ADARI dapat disebut meminjam istilah Imam Thalhah adalah suatu Paguron (ajaran) bukan merupakan organisasi seperti lain-lain gerakan mistik ${ }^{2}$. Aliran ini membawa suatu nuansa baru karenanya sambutan dari berbagai lapisan mempunyai nilai yang

3Imam Tholheh, Mewaspadai dan Mencegab Konflik. Antar Umat Beragama, Badan Litbang Agama dan Diklat Keagamaan Proyek Peningkatan kerukunan hidup umat beragama, Jakarta, 2001, h; 1.

${ }^{2}$ Kamil Kartapradja, Aliran Kebatinan dan Kepercayaan di Indonesia, Yayasan Masaagung, Jakarta, 1985, h; 170. 
berbeda ada yang pro, sebaliknya tidak sedikit yang kontra terhadap hal ini. Sebagai yang menganut agama Islam tentunya akan seolah-olah terjawab sendiri dengan hadirnya firman Allah dalam Alquran. Begitu juga dari falsafah bangsa Indonesia sebagai pemerintah hanya melegalkan agama yang lima dan yang terakhir muncul agama baru, yakni Konghucu.

Secara organisatoris ADARI adalah singkatan dari Agama Djawa Asli Republik Indonesia, dilihat dari latar belakang historis kelahirannya adalah bermula ketika Mangun Widjojo sebagai pendiri aliran ini mendapat ilham. ${ }^{3}$ Beliau pada saat itu di sel dalam penjara Waragunan Yogyakarta. Namun kalau melihat dari ajarannya, ADARI ialah penjelmaan dari BASRI (Barisan Semedi Republik Indonesia) yang ada di Surakarta atas pimpinan KI Cokrowardoyo pendiri laskar rakyat Kesunanan dan Mangkunegara waktu di zaman permulaan revolusi kemerdekaan Indonesia kira-kira sekitar tahun $1946^{4}$.

Oleh karena itu tidak mengherankan kalau ADARI di Surakarta, mendapat sambutan baik dan juga pembantu-pembantunya yang disebut Pimpian Cabang ADARI di Surakarta. Waktu pimpinan pusatnya dari Yogyakarta datang di Kebumen dengan maksud menyebarkan ajarannya (ADARI), menerangkan kepada salah seorang wartawan, bahwa ilmu yang diajarkannya itu dinamakan Jawa Asli, nama tersebut bukan suatu pokok, tidak merupakan organisasi atau menjadi suatu ilmu. Adapun dengan memberi nama Jawa Asli ialah sekedar menjadi dasar ajaran yang diberikannya. Ilmunya itu lepas dari ajaran agama-agama yang ada yang bersumber pada kitab-kitab Alquran, Injil dan Taurat, juga tidak mengambil dari buku-buku yang ada. Demikian pula dengan doa atau mantra-mantranya tidak diambilkan dari salah satu kitab tersebut di atas. Semua ajarannya diberikan dengan lisan, peribadatannya tidak seperti peribadatan agama-agama yang sudah ada seperti sujud, rukuk dan sebagainya dengan maksud menyembah Tuhan.

Perlu diketahui bahwa sebagai persyaratan untuk orang yang ingin masuk anggota ADARI terlebih dahulu harus berpuasa selama tujuh hari untuk membersihkan diri. Sesudah itu barulah diberikan pengajaran dan pelajaran seperlunya, seseorang yang telah membersihkan diri itu akan lebih mudah bertemu dengan Pangeran Pribadi.ADARI mengangkat Bung Karno menjadi Nabinya dan Pancasila menjadi kitabnya, begitu pula peraturan-peraturan yang keluar dan berlaku dari pemerintah

\footnotetext{
3"Joyowolu yang nama aslinya adalah S.W. Mangung Widjojo, kemudian ganti nama dengan gelar Ki Mangungwasito lahir kira-kira pada tahun 1829 di Surakarta. Ia tamat sekolah rakyat dan mulai tahun 1922 bekerja di bengkel DKA di Pengok (Yogyakaarta) sampai akhir dengan mendapat pensiun. Ia pernah masuk BASRI (Barisan Semedi Republik Indonesia) dengan lebih dahulu berpuasa. Pada tanggal 1 Agustus 1946 pernah bertapa di Pasareyan (makam) Imogiri Pasareyan Paku Buwono IX, pada waktu itumendapat Ilham untuk menyebarkan ilmunya itu"

${ }^{4}$ Kamil Kartapradja., Op-Cit, h; 173.
} 
Republik Indonesia adalah kitabnya. ${ }^{5}$ Akan tetapi pengangkatan diri Soekarno sebagai Nabi pada hakekatnya tidaklah mendapat sambutan secara baik, namun sebaliknya yaitu ketidak siapannya.

Atas pernyataan tersebut di atas Ki Mangunwasito, pemimpin pusat ADARI, membuat reaksi dengan keterangan bahwa ADARI menganggap Bung Karno itu Nabi, yaitu ketika beliau memperoklamasikan kemerdekaan Indonesia dan menciptakan Pancasia. Pada waktu Bung Karno oleh ADARI dianggap Hyang Wasesa Ning Tunggal. ADARI mempunyai paham bahwa Nabi ialah pimpinan tertinggi yang dapat menciptakan suatu peraturan yang dapat dipakai untuk dasar Negara dan diakui oleh seluruh rakyat Indonesia. Dalam bahasa yang lebih sederhana, "Mangun Wijoyo mengembangkan ajaran ADARI sebagai agama asli Republik Indonesia dimana ajarannya itu suatu agama dengan prinsip manunggaling Kawula Gusti, Bung Karno diangkatnya jadi Nabi sekaligus titisan Tuhan."

Meskipun ADARI menganggap Bung Karno sebagai Nabi, tetapi tidak mengumpulkan dalildalil yang dikeluarkan oleh Bung Karno yang cukup banyak dimuat di Pers, pengumuman di radio, buku-buku yang disiarkan oleh kementerian penerangan dan sebagainya. KI Mangunwasito pernah menyatakan, bahwa waktu Majapahit jatuh, orang masuk Islam, waktu penjajahan Jepang orang tunduk kepada Tenno Haika. Sekarang Indonesia sudah merdeka, masyarakat harus memeluk Agama Jawa Asli, demikian pernyataan dari beliau.

Padahal, jikalau diinterpretasi bahwa "kepercayaan" ini merupakan aliran pemikiran yang mengambang yang tidak mempunyai pembakuan atas ajarannya dan tidak punya historis peradaban sebagaimana agama-agama besar. Hal itu menunjukkan bahwa masyarakat Indonesia adalah masyarakat yang mudah menerima perkembangan agama bahkan membentuk kepercayaan baru yang dianggap dapat membawanya ke dalam suatu kebahagiaan. Sebagai salah satu contoh, adalah ajaran ADARI yang berkembang di Jawa hingga sampai sekarang telah berkembang sebagai suatu kepercayaan dan bahkan telah ditetapkan dalam GBHN.

Secara yuridis yang dijadikan landasan argumentasi untuk membenarkan masuknya aliran kepercayaan ke dalam GBHN ialah frase pada Pasal 29 ayat 2 yaitu: "...menurut agamanya dan kepercayaannya itu..." Berdasarkan frase "kepercayaannya itu" maka dipaksakanlah masuknya "aliran

${ }^{5}$ Karena pendirian mengenai Nabi agak ganjil, maka timbul desas-desus di kalangan rakyat, terutama Umat Islam, bagaimana reaksi Presiden Soekarno yang dianggap menjadi Nabi, karena selama ini belum pernah menatakan atau menerima dianggap Nabi oleh seseorang atau suatu golongan. Untuk mengatasi hal itu, salah seorang pegawai tinggi kementerian (Departeman) agama Republik Indonesia menyatakan kepada wartawan kedaulatan rakyat yang diberitakan di dalam harian tersebut 22 April 1959, bahwa Bung Karno tidak menerima diangkat menjadi Nabi.

${ }^{6}$ Rahnip M. BA, Aliran Kepercayaan dan Kebatinan Dalam Sorotan, Pustaka Progressif, Surabaya, 1987, h; 230, 
kepercayaan" ke dalam GBHN. Pendapat yang menyatakan bahwa yang dimaksudkan dengan frase "dan kepercayaannya" itu adalah pengakuan atas aliran kepercayaan, adalah sangat dicari-cari. Dengan mengenal adanya nama "aliran kepercayaan kepada Tuhan YME" itu baru pada tahun 1977, namun dalam kenyataannya aliran kepercayaan ini sering juga disebut sebagai "alairan kebatinan".

Di samping perkembangan agama besar ini (Hindu, Budha, Kristen dan Islam) penganut kepercayaan ini juga berkembang sejajar dengan perkembangan masyarakat Indonesia, dan bahkan dapat dikatakan pengaruhnya cukup besar di kalangan rakyat Indonesia khususnya di Jawa. Hal ini terbukti dengan berbagai tulisan dan peristiwa yang terjadi pada masanya sehingga dapat mewariskan dan menyebarkan berbagai macam budaya, tradisi, nilai, dan kepercayaannya kepada masyarakat di sekitarnya maupun generasi penerus. Bukti-bukti tertulis yang ditinggalkan sehingga dapat dibaca dan dipelajari oleh generasi selanjutnya, kemudian dapat dipahami dan ditafsirkan sebahagian gambaran kehidupan generasi terdahulu dan memperkuat akar dan jati diri masyarakat yang bersangkutan.

Suatu hal yang terungkap dalam historis adalah bahwa aliran kepercayaan di Indonesia terwujud dari konsekwensi logis yang memang para penganut agama kurang memperhatikan, memahami juga kurangnya kepuasan terhadap apa yang dimiliki atau diamalkan disisi lain adalah pengaruh pergolakan pemikiran, sinkritisme dari adat dan budaya yang berbeda. ${ }^{7}$ Satu contoh yang bisa diambil dalam satu historis adalah ADARI yang menjadi refleksi kemajuan, namun akal dan pikiran terus dipotensikan untuk mencari hakikat kebenaran sehingga muncul objek kajian dalam bidang kosmosentris, theosentris yang pada akhirnya berkembang pola pikirnya untuk mencari hakekat Tuhan. ${ }^{8}$

Berdasarkan beberapa referensi menyebutkan, bahwa munculnya ajaran ADARI ini dipelopori oleh Mangun Widjoyo sewaktu berada di penjara (berada dalam sel) Wirogunan Yogyakarta. Bahkan menurut pengakuannya, bahwa selama berada dalam penjara itu ia mengadakan perenungan atau semedi, sehingga datanglah petunjuk berupa wangsit kepadanya agar segera mengembangkan suatu ajaran hasil perenungannya yaitu Manunggaling Kawula Gusti, Bung Karno diangkatnya menjadi Nabi yang sekaligus sebagai titisan Tuhan. Untuk penjelasan dan auraian yang lebih luas, mari disimak uraian-raian selanjutnya.

${ }^{7}$ Hasbulah Bakrie, Pedoman Islam di Indonesia, UI Press, 1990, h; 34.

${ }^{8} \mathrm{Hal}$ ini menjadi sejarah dalam perkembangan Filsafat Yunani di abad ke V. Lihat Hasan Bakti Nasution, Filsafat Umum, Cita Pustaka Media, Bandung, 2001, h; 71. 


\section{Beberapa Doktrin Ajaran Aliran ADARI}

Asas dan tujuan pokok ajaran aliran ADARI adalah melaksanakan Pancasila, Kebebasan, Keadilan Sosial, Ketuhan Yang Maha Esa yang mempertinggi kebudayaan Indonesia (Jawa Asli). Oleh karena itu, nampaknya tidak terlalu berlebihan kalau dikatakan bahwa ADARI ini adalah aliran yang asli Indonesia sebab memang aliran ini hanya ada dan dikenal di Indonesia, serta ditambah lagi kedekatan aliran kebatinan ADARI yang sangat dekat dengan ideologi bangsa Indonesia.Dalam teknis pelaksanaan keyakinan doktrinnya ADARI ini Kamil Kartapradja mengklasifikan pada beberapa bentuk keyakinan. ${ }^{9}$ yaitu :

1. Tidak menganut salah satu idiologi politik, Kedua, Ajaran kebatinan yang menuju ketuhanan yang Maha Esa yang asli dan kesempurnaan hidup, Ketiga, Mengadakan perkawinan sendiri, caranya harus ada persetujuan antara bakal pengantin laki-laki dan perempuan dengan mupakat dari wali kedua belah pihak, kemudian disaksikan oleh pemimpin ADARI setempat. Juga diberi surat keterangan kawin dengan membayar Rp. 8,50.

2. Tiap hari Ahad mengadakan selamatan, namanya Rasulan

3. Tidak menarik iuran. ${ }^{10}$

Dalam kaitan ini ada sesuatu kisah yang menarik untuk diketengahkan, yaitu bahwa suatu ketika saat Joyowulo atau nama aslinya S.W. Mangunwjoyo pernah kirim surat kepada Presiden Soekarno, bahwa ia selalu tapa brata kungkum (bertapa merendam diri) di Kali Opak tiap selapan dina (35 hari) sekali. Demikian pula anggota-anggota ADARI diperintahkan tirakat puasa mutih (hanya makan nasi). Menurut Kamil Kartapradja tujuan dari pelaksanaan ritual ini maksudkan pada beberapa hal, di antaranya:

1. Tuhan Yang Maha Esa melindungi tentara kita.

2. Tuhan Yang Maha Esa memberi bimbingan yang baik kepada Tuhan pimpinan-pimpinan kita.

3. Tuhan Yang Maha Esa lekas memasukkan Irian Barat ke wilayah Republik Indonesia.

4. Tuhan Yang Maha Esa menghancurkan koruptor-koruptor.

5. Pemberontak-pemberontak mendapat hukuman yang setimpal.

6. Pemerintah Republik Indonesia lekas membuat Undang-Undang Perkawinan.

7. Pemerintah mengakui ADARI sebagai agama seperti agama-agama yang lain. ${ }^{11}$

${ }^{9}$ Kamil Kartapradja, Op.cit, h; 173.

${ }^{10}$ Ibid., h; 171 
Dalam teknis pelaksanaan ritual aliran ADARI umpamnya pada salah satu tempat di Surakarta anggota-anggota ADARI kalau menghadiri perkawinan dan sebagainya memakai pakaian serba hitam, sebab katanya itulah pakaian Jawa asli. Seorang anggota ADARI pernah diwawancarai oleh seorang wartawan, bagaimana hubungan ADARI dengan Tuhannya, karena menurut keterangan pemimpin pusatnya bahwa anggota-anggota ADARI tidak diajarkan sujud dan sebagainya, tetapi pengikut ajaran ADARI tiap pagi harus menghadap ke Timur, siang ke atas, sore ke Barat dan waktu malam semedi. ${ }^{12}$ Semula itu dilakukan dengan duduk sambil menghening cipta, pada waktu semedi terus mengheningkan cipta sampai mendapat ilham (wangsit). Sedangkan untuk hari-hari besar ADARI dapat disebut pada tanggal 1 Syura, yaitu tanggab Warsa (Tahun Baru) dan tanggal 17 Pasa (Ramadhan) dianggap hari kemerdekaan karena 17 Agustus 1945 itu merupakan hari 17 Pasa 1876 H.

\section{Doktrin Ketuhanan ADARI}

Berbicara tentang masalah doktrin sebagaimana umumnya agama-agama formal ADARI juga memiliki beberapa doktin yang berkaitan dengan Tuhan. Dalam masalah doktrin kepercayaan tentang Tuhan ADARI meyakini bahwa setiap manusia yang memiliki agama pada hakekatnya mempercayai akan adanya Tuhan. Namun, dalam konsep ketuhanannya ini tidaklah sama antara satu dengan lain dalam tingkatan pengamalannya, seperti dalam agama Hindu percaya akan Tuhan, agama Kristen percaya pada Tuhan Yesus, Islam percaya pada Allah Swt.

Sedangkan dalam kepercayaan ajaran ADARI juga percaya akan adanya Tuhan yakni mengajarkan bahwa Tuhan Yang Maha Esa adalah pencipta dan azas bagi segala yang ada. Tuhan tidak bisa digambarkan bagaimana keadaannya dan tidak bisa dicontohkan. Berdasarkan ajaran yang diperoleh Mangun Widjoyo yakni sebagai pendiri dari pada ADARI ini menyatakan, bahwa Ia memperoleh Sasmito dari Tuhan atau Pelambang dari Tuhan, karena mustahil (tidak bisa) Tuhan menjelma dalam badan Mangun Widjoyo. Kapan saja "sasmita" itu tiba, maka mangun Wdjoyo sanggup melihat dan meramalkan hal-hal ajaib. ${ }^{13}$

Sesuai dengan keterangan yang ada, sebenarnya Mangun Widjoyo beroleh sasmita yang katanya dari Gusti, hampir saja ia mengangkat dirinya sendiri sebagai Nabi, tetapi untung saja Gusti tidak bisa menjelma ke dalam tubuhnya. Tetapi untuk gantinya (karena Gustinya tak sanggup menjelma ke dalam diri Mangun Widjoyo), maka Gusti mendatangkan sasmita kepadanya berupa

${ }^{11}$ Ibid., h; 173

${ }^{12}$ Rahmat Subagya, Kepercayaan dan Agama "Kebatinan Kerohanian dan Kejiwaan”, Kanisius, Jakarta, 1995, cet. Ke II, h; 9.

${ }^{13}$ M. As'ad El-Hafidy., Op-Cit., h; 30. 
Pelambang dari Gusti. ${ }^{14}$ Bilamana sasmita itu datang kepadanya, akhirnya Mangun Widjoyo akan sanggup melihat dan meramalkan hal-hal yang gaib dan ajaib.

Hal lain yang menyatakan bahwa Mangun Widjoyo tentang ramalan ajaib, kedatangan sasmita adalah dikala beliau sedang "kungkum" menyelam di pemandian Umbang Tirto di dekat lapangan Kridosono Yogyakarta, beliau menyaksikan seekor buaya yang memakai "kuluk" selubung putih, berjalan ke arah Barat dan terdengarlah suara di telinganya: "Kondoa karo Kepala Daerah Kotapraja". ${ }^{15}$ Dalam peristiwa itu disampaikan bahwa suatu ketika mestinya Kartosuwiryo terangkat menjadi sebuah pemimpin yang aman dalam menjalankan roda pemerintahan di Indonsia. Namun dalam kenyataannya, Kartosuwiryo tidak dapat memerintah sebagai mana mestinya dan ia mati terbunuh oleh pemerintah.

Dalam upaya upaya melengkapi doktrin tentang Tuhan ini aliaran ADARI juga mempercayai kepercayaan tentang Kawula Gusti. Menurut M. As'ad el-Hafidy konsep manunggal dalam ajaran ADARI bermaksud ADARI menurut artian adalah Agama Jawa Asli, para penganutnya mengangkat Ir. Soekarno menjadi Nabi sebagai utusan Tuhannya atau Gusti menurut sementara pengikutnya. ${ }^{16}$ Lebih lanjut el-Hafidy mengatakan sedangkan Gustinya itu telah Manunggal menjadi satu dalam diri Bung Karno. Terjadilah Gusti sama dengan Bung Karno dan Bung Karno sama dengan Gusti. ${ }^{17}$

Menurut aliran kebatinan ADARI sebagaimana yang disebutkan el-Hafidy bahwa Bung Karno itu menerima titisan Gusti, artinya Gusti menjelma ke dalam diri Bung Karno, sedangkan Bung Karno tidak dapat masuk ke dalam Gusti. Manunggal dengan Gusti berarti Gusti menitis ke dalam dirinya. Begitu aqidah Manunggaling Kawula Gusti. Ketika Manunggal itu terjadi, maka Bung Karno itulah Gusti adanya, sehingga segala perbuatan Bung Karno, maupun kata-katanya adalah perbuatan dan ucapan Gusti. ${ }^{18}$

Gusti yang Maha Esa telah "manunggal” menjadi satu dalam diri Bung Karno. Dalam kata lain Bung Karno menerima titisan Gusti yang Maha Esa sehingga Manunggal menjadi satu. Dus Gusti sama dengan Bung Karno, Bung Karno sama dengan Tuhan. Gusti yaitu Bung Karno sendiri yang dimasuki Tuhan yang Esa pada waktu manunggal. Disaat Bung Karno manunggal maka segala

${ }^{14}$ Rahnip., Op-Cit., h; 323

${ }^{15}$ Kondoa karo Kepala Daerah Kotapraja, adalah merupakan suatu pertanda dan pernyataan bahwa di Indonesia akan datang seseorang yang akan menjadi pemimpin dan dapat membwa perubahan Indonesia dalam satu system pemerintahan yang bercorak religious, yakni Kartosuwiryo. Kejadian atau peristiwa tersebut terjadi di Malam Jum'at jam 24.00 hingga jam 03.00 waktu stempat., M. As'ad el-Hafidy., Op-cit.,

${ }^{16} \mathrm{Ibid}$,

${ }^{17} \mathrm{Ibid}$.

18Rahnip., Op-Cit., h; 231-232. 
ucapan yang diucapkan Bung Karno adalah kata-kata Tuhan, serta apa yang dilakukan Bung Karno adalah tindakan Tuhan. Tuhan dapat menjelma ke dalam diri Bung Karno walaupun Bung Karno tidak dapat masuk ke dalam Tuhan. Maksudnya : Tunggal dengan Tuhan, Tuhan menitis ke dalam diri seseorang. ${ }^{19}$ Dengan demikian, Bung Karno dalam ajaran ADARI adalah sosok mausia yang di dalam dirinya ada titisan Gusti. Dengan titisan Tuhan ini beliau dapat berbuat sesuai dengan apa yang dikehendaki, sedang untuk masyarakat penganutnya ajaran tentang Tuhan dan Manunggaling Kawula Gusti merupakan ajaran atau doktrin yang harus diikuti dengan sebenarnya tanpa ada unsur keragu-raguan di dalam diri manusia itu.

\section{Penutup}

Berdasarkan pemaparan di atas dapat dikatakan bahwa sebenarnya aliran ADARI lahir dan berkembangan tidak dapat dipisahkan dari agama formal. Karena memang secara personal para pendiri aliran ini adalah orang-orang yang merupakan bagian dari pengamal agama formal tersebut. Menariknya adalah bahwa ternyata dalam perkembangan dokrin aliran ADARI ini dapat disebut merupakan upaya pengakumulasian dari berbagai agama-agama. Hal ini sangat jelas terlihat dalam dokrtinnya tentang ketuhanan yang tidak dibedakan sebagaiaman lazimnya agama-agama formal.

Begitu juga tentang masalah kemungkinan penyatuan dengan Tuhan (Manunggaling Kawula Gusti) nampaknya aliran ADARI ini sangat berkaitan langsung dengan aliran kebatian yang telah ada sebelumnya, terutama yang ada di Jawa. Walaupun memang sebenarnya dalam agama-agama formal juga dikenal konsep Manunggaling Kawula Gusti tersebut. Oleh sebab itu, dapat ditegaskan bahwa ADARI ini sebelumnya adalah upaya penyatuan dari tradisi-tradisi yang ada di dalam agama formal.

\section{Daftar Pustaka}

Bakrie, Hasbulah, Pedoman Islam di Indonesia, UI Press, 1990.

Kartapradja, Kamil, Aliran Kebatinan dan Kepercayaan di Indonesia, Yayasan Masaagung, Jakarta, 1985.

Nasution, Hasan Bakti, Filsafat Umum, Cita Pustaka Media, Bandung, 2001.

Rahnip M. BA, Aliran Kepercayaan dan Kebatinan Dalam Sorotan, Pustaka Progressif, Surabaya, 1987.

Subagya, Rahmat, Kepercayaan dan Agama "Kebatinan Kerohanian dan Kejïwaan”, Kanisius, Jakarta, 1995.

Tholheh, Imam, Mewaspadai dan Mencegah Konflik. Antar Umat Beragama, Badan Litbang Agama dan

Diklat Keagamaan Proyek Peningkatan kerukunan hidup umat beragama, Jakarta, 2001.

${ }^{19}$ M. As'ad el-Hafidy., Op-Cit., h; 30-31. 